\title{
Incidence and Etiology of Postharvest Fungal Diseases of Persimmon (Diospyros kaki Thunb. cv. Rojo Brillante) in Spain
}

Lluís Palou, Clara Montesinos-Herrero, Ignacio Tarazona, Cristina Besada and Verónica Taberner, Laboratori de Patologia, Centre de Tecnologia Postcollita (CTP), Institut Valencià d'Investigacions Agràries (IVIA), Apartat Oficial, 46113 Montcada, València, Spain

\begin{abstract}
Palou, L., Montesinos-Herrero, C., Tarazona, I., Besada, C., and Taberner, V. 2015. Incidence and etiology of postharvest fungal diseases of persimmon (Diospyros kaki Thunb. cv. Rojo Brillante) in Spain. Plant Dis. 99:1416-1425.

'Rojo Brillante' is currently the most important persimmon cultivar in Spain. The incidence and etiology of postharvest diseases affecting this cultivar were determined under local conditions. Latent and wound pathogens were assessed for two consecutive seasons on commercially grown persimmons from two orchards. Healthy persimmons were either surface-disinfested or artificially wounded on the rind and placed in humid chambers at 20 or $25^{\circ} \mathrm{C}$ for up to 9 weeks. Additionally, decay was assessed on commercially handled persimmons stored at $1^{\circ} \mathrm{C}$ for up to 20 weeks. In all cases, the most frequent disease was alternaria black spot (ABS) caused by Alternaria alternata and an ABS severity index specific for 'Rojo Brillante' persimmons was established. Other minor pathogens

causing latent infections, mostly stem-end rots, included Botrytis cinerea, Lasiodiplodia theobromae, Neofusicoccum spp., Pestalotiopsis clavispora, and Colletotrichum gloeosporioides. Penicillium expansum and, to much a lesser extent, Cladosporium cladosporioides were other pathogens causing wound infections. These two fungi and A. alternata and $B$. cinerea were also isolated from cold-stored fruit. Common isolates were identified by macroscopic and microscopic morphology and/or DNA amplification and sequencing. Pathogenicity of selected isolates was demonstrated by fulfilling Koch's postulates. Disease development at 20 and $5^{\circ} \mathrm{C}$ was characterized on artificially inoculated persimmons.
\end{abstract}

In recent years, cultivation of Asian or sweet persimmon (Diospyros kaki Thunb.) in Spain has greatly increased to reach a planted area of about 13,300 ha, with an annual production of 150,000 tn. This production is concentrated in two main persimmon growing areas, València (88\% of total planted area) and Andalucía $(9.7 \%$ of total planted area), and it is based on two major cultivars that are astringent at harvest: 'Rojo Brillante', mainly cultivated in València and 'Triumph' (syn.: 'Sharon'), mainly cultivated in Andalucía (ESYRCE 2014). The most important cause for this production increase and, therefore, for increasing economic benefits for Spanish persimmon growers, is the widespread adoption of a new postharvest technology to efficiently remove the astringency of the fruit without harm to fruit quality. This deastringency procedure, based on the application of carbon dioxide $\left(\mathrm{CO}_{2}\right)$ concentrations as high as 95 to $98 \%$ at $20^{\circ} \mathrm{C}$ for $24 \mathrm{~h}$ (Arnal and del Río 2003) allows Spanish persimmon to be commercialized with a crisp texture that has been accepted by major export markets (EU countries such as Germany, France or The Netherlands) (Martínez-Calvo et al. 2012). On the other hand, the elevated firmness of fruit subjected to this procedure reduces mechanical injuries and deterioration risks associated to intense postharvest manipulation. This has improved appeal of the fruit to consumers and increased the number of market destinations, particularly for 'Rojo Brillante' persimmons.

The ripening period of 'Rojo Brillante' persimmons is brief (typically October to December) and fruit storage is necessary to maintain the quality of harvested fruit and extend commercial periods. Fruit of this cultivar are sensitive to chilling injury when stored at low temperatures and many workers have pursued the control of this physiological disorder (Arnal and del Río 2004; Ben-Arie et al. 2001; Besada et al. 2008b, 2014; Salvador et al. 2004a). Nowadays, 1-methylcyclopropene

Corresponding author: L. Palou; E-mail: palou_llu@gva.es; Tel. +34 963424117

Accepted for publication 22 April 2015.

http://dx.doi.org/10.1094/PDIS-01-15-0112-RE

(C) 2015 The American Phytopathological Society
(1-MCP), an ethylene inhibitor, is applied routinely in the packinghouse to 'Rojo Brillante' fruit before cold storage because it effectively reduces chilling injury, allowing prolonged storage at $0-1^{\circ} \mathrm{C}$ (Besada et al. 2008a; Salvador et al. 2004a). In addition, the storability of 'Rojo Brillante' at moderate temperatures $\left(15^{\circ} \mathrm{C}\right)$ has also been prolonged by 1-MCP treatment (Salvador et al. 2004b). Currently, the Spanish persimmon industry is clearly interested in prolonging as far as possible fruit storage life to reach off-season markets and new emerging technologies such as the application of 1-MCP in combination with controlled atmosphere storage are thus under study (Besada et al. 2014). However, such extension of fruit postharvest life has been increasingly compromised in recent seasons by the high incidence of postharvest diseases caused by fungal pathogens, especially alternaria black spot (ABS), caused by Alternaria alternata (Fr.:Fr.) Keissler (Palou et al. 2012).

In general, postharvest decay can be caused in persimmon by fungal inoculum that infects the fruit through injuries or microwounds located on any part of the skin (wound pathogens) or by inoculum that infects the flowers or young fruits in the field, remains latent, and develops after harvest (latent pathogens). Additionally, some pathogens are able to infect stored persimmons by mycelial spread from infected fruit to adjacent healthy fruit, causing "nests" of decay. Economic losses caused by the development of postharvest diseases is especially important when the level of latent fungal infections at the time of harvest is high or a substantial proportion of fruit is superficially damaged (Prusky et al. 1981a, b). In any case, the type and incidence of fungal infections determine every season the potential economic losses caused by postharvest diseases and dictate the most adequate postharvest handling procedures to minimize such losses. This is even more important in Spain and other EU countries where no conventional chemical fungicides are currently permitted for postharvest treatment of persimmon and disease control strategies would rely on the integration of alternative nonpolluting methods.

The objectives of this research were to quantify and identify fungal infections causing postharvest diseases on 'Rojo Brillante', the most commercially important persimmon cultivar in Spain. Disease was assessed on intact fruit from the field, artificially wounded fruit, and commercially handled fruit subjected to prolonged cold storage. Tests to prove pathogenicity and characterize disease development 
were also conducted with some fungi frequently isolated from persimmon. Some preliminary results from this study have been published (Palou et al. 2009, 2012, 2013a, b).

\section{Materials and Methods}

Fruit. For two consecutive harvest seasons (2009 and 2010), persimmons (Diospyros kaki Thunb.) cv. 'Rojo Brillante' commercially grown in two different orchards in L'Alcudia area (Lat. $39.11 \mathrm{~N}$, Long. $0.30 \mathrm{~W}$; Ribera Alta, València, Spain) were harvested at commercial maturity and transported to a local packinghouse. Both orchards were representative of persimmon plantings and handling in the area. Average values (two seasons) for fruit quality attributes at harvest were: flesh firmness $=39.6 \mathrm{~N}$; soluble solids content $(\mathrm{SSC})=12.3 \%$; color index $(\mathrm{CI}=1000 * a / L * b$, where $L, a$, and $b$ are Hunter parameters $)=12.7$. One day later, intact persimmons were transported to the CTP IVIA facilities where sound fruits of uniform medium size were selected, randomized, and used the same day in the experiments to assess disease on intact and wounded fruit. Another set of fruit were commercially handled in the packinghouse and used for assessment of decay during cold storage as described below.

Assessment of latent disease. Intact healthy persimmons from the field were selected, surface-disinfested by dipping them for $1 \mathrm{~min}$ in an aqueous $0.5 \%$ sodium hypochlorite solution, thoroughly rinsed with fresh water, dried with paper towels, and placed on the surface of sterile petri dishes (base or lid) inside humid chambers. Humid chambers consisted of 5-L plastic containers with lids that had been surface-disinfested by spraying with $98 \%$ ethanol and allowing them to air-dry at room temperature. To allow air exchange, a $0.5-\mathrm{cm}$ diameter hole was made in two opposite walls of each container. Paper towels soaked with sterile water were placed on the bottom of each container. Closed humid chambers were incubated at $25^{\circ} \mathrm{C}$. Each season, eight replicate humid chambers, each containing four persimmons, were prepared with fruit from each orchard. Fruit infections in each chamber were recorded weekly for 9 weeks. All fungal infections on each fruit were recorded. Isolation and identification of uncertain, common fungal isolates and pathogenicity tests were performed when needed as described below.

For the specific case of fruit infected by A. alternata, that were clearly the most abundant, evaluations were performed at each evaluation date assessing ABS incidence (percentage of fruits showing ABS symptoms) and ABS index, a specific disease severity index for 'Rojo Brillante' persimmons on a scale of 0 to 5 . The establishment of this index is described in detail in the Results section.

Assessment of disease on artificially wounded fruit. Persimmons from the field were each wounded at eight equidistant points along the cheek with a sterilized stainless steel probe, $1 \mathrm{~mm}$ wide and $2 \mathrm{~mm}$ long. Each wounded fruit was placed on a numbered sterile Petri dish base or lid and the dishes were put inside humid chambers and incubated as described above. For each season, eight replicate humid chambers, each containing four persimmons (32 wounds), were prepared with fruit from each orchard. The number of infected wounds was recorded weekly for 7 weeks at $20^{\circ} \mathrm{C}$. Common unknown fungi were isolated and identified as described below. Pathogenicity tests were performed when necessary.

Assessment of disease during cold storage of commercially handled fruit. Persimmons that had been commercially handled in the packinghouse were brought one day later to the IVIA and stored in a $40-\mathrm{m}^{3}$ standard research cold storage room at $1{ }^{\circ} \mathrm{C}$ and $90 \% \mathrm{RH}$ for 10 weeks in 2009 and for 20 weeks in 2010. Procedures in the packinghouse included the application of a treatment to remove fruit astringency (exposure of 20-kg plastic field boxes to $95 \% \mathrm{CO}_{2}$ for about $24 \mathrm{~h}$ at room temperature) and packingline processing, which involved visual inspection, hand-selection, surface washing, forcedair drying, automatic sorting and grading by size, and packaging of the fruit in $59 \times 30 \times 12 \mathrm{~cm}$ lidless cardboard boxes with plastic cavity trays that prevented contact between fruit. No waxing or any other postharvest treatment was applied. Each season, four replicate commercial boxes, each containing 24 'Rojo Brillante' persimmons, were used with fruit from each orchard (96 fruits per orchard). All fungal infections on each fruit were recorded. Fruit infections, ABS incidence and ABS index were recorded every two weeks during the cold storage period. If needed, fungal isolation and identification and pathogenicity tests were performed as described below.

Isolation and identification of fungi. In all of the above disease assessment procedures, infections with distinctive symptoms were recorded directly. Otherwise, putative causal agents were isolated from decayed fruit following one of these two procedures depending on the type of decay symptoms: i) when symptoms were surface spots or bruises with apparent external fungal mycelia or spores, samples of these fungal structures were taken with a sterile Kolle inoculating loop or needle and plated directly onto potato dextrose agar (PDA) in 9-cm diameter Petri dishes; ii) when symptoms were surface spots or bruises with no apparent fungal growth, the diseased area was surface-sterilized with $98 \%$ ethanol and 5-mm diameter segments of infected tissue were cut and plated in sterile conditions onto PDA. In all cases, inoculated PDA plates were incubated in the dark at $25^{\circ} \mathrm{C}$. Where necessary, fungal isolates were subcultured on PDA and identified on the basis of macroscopic and/or microscopic morphology. With some exceptions, fungi were identified at genus level.

Isolates that commonly occurred but could not be identified were submitted to specialized professional laboratories, i.e., the Spanish Type Culture Collection ('Colección Española de Cultivos Tipo', CECT, University of Valencia, València, Spain) and the 'Instituto Valenciano de Microbiología' (IVAMI, Bétera, València, Spain), for identification on the basis of morphology of colonies growing on different culture media and different temperatures, and by the amplification and subsequent sequencing of the ribosomal DNA intragenic spacer regions ITS1 and ITS2 along with the 5.8S rRNA gene (White et al. 1990). In some cases, the region D1/D2 in the $5^{\prime}$ end of the 28S rDNA gene was also sequenced. Where necessary, pathogenicity tests were performed, as described below.

Pathogenicity tests and characterization of disease development. Fungi isolated from decayed persimmons that were tested for pathogenicity and characterization of disease development include Lasiodiplodia theobromae (Pat.) Griffon \& Maubl., Neofusicoccum mediterraneum Crous, M.J. Wingf. \& A.J.L. Phillips, Neofusicoccum luteum (Pennycook \& Samuels) Crous, Slippers \& A.J.L. Phillips, Colletotrichum gloeosporioides (Penz.) Penz. \& Sacc., Pestalotiopsis clavispora (G. F. Atk.) Steyaert, A. alternata, Penicillium expansum L., and Cladosporium cladosporioides (Fresen.) G.A. de Vries. The first five species were inoculated in recently harvested healthy 'Rojo Brillante' persimmons as follows: 5-mm diameter mycelial plugs from 7- to 14day-old colonies grown on PDA at $25^{\circ} \mathrm{C}$ were aseptically transferred to 5-mm diameter, 2-3-mm depth wounds inflicted in the equatorial area of the fruit peel with a sterile cork borer (two wounds per fruit on opposite cheeks). Fruit inoculated with sterile discs of agar served as controls. The latter three species were inoculated on healthy persimmons as follows: fruit were wound-inoculated in four equidistant points in the equator with a sterilized stainless steel probe, $1 \mathrm{~mm}$ wide and $2 \mathrm{~mm}$ long, previously immersed in a spore suspension of each fungus containing $10^{6}$ spores $\mathrm{mL}^{-1}$. Fruits prepared similarly with a probe immersed in sterile water served as controls.

In every case, irrespective of the inoculation procedure, the fruit were superficially disinfested by dipping for $2 \mathrm{~min}$ in $0.5 \%$ aqueous sodium hypochlorite and thoroughly rinsed with deionized water. Inoculated fruit were placed in humid chambers as previously described and incubated at $20^{\circ} \mathrm{C}$ or stored at $5^{\circ} \mathrm{C}$. Four chambers containing four persimmons were used for each fungus and temperature. Additional chambers with four noninoculated persimmons were used as controls. Depending on the fungus and storage temperature, the number of infected fruit, the lesion size, and the number of fruit showing spores were determined every 3 to 7 days during incubation at $20^{\circ} \mathrm{C}$ of up to 22 days and every 7 to 14 days during storage at $5^{\circ} \mathrm{C}$ of up to 75 days. To fulfill Koch's postulates, reisolations to PDA plates in aseptic conditions were made after 7 days of incubation at $20^{\circ} \mathrm{C}$ from inoculated persimmons showing disease symptoms. The tests were conducted twice.

Statistical analyses. On both intact and commercially-handled and cold-stored fruit, the incidence of ABS (i.e., percentage of fruit 
showing disease symptoms) and the ABS index (score 0-5) were considered as dependent variables. On artificially inoculated fruit, total disease incidence, i.e., percentage of wounds infected by any pathogen, designated 'all pathogens', incidence of decay caused by each common pathogen, and incidence of decay caused by sporadic or uncommon pathogens (designated 'other pathogens'), were considered as dependent variables. For each evaluation date and type of disease assessment, incidence data were arcsine transformed and two-way analyses of variance (ANOVA), with season and orchard as random factors, were performed using SAS software (SAS Institute Inc., Cary, NC, USA). In the case of artificially inoculated fruit, an analysis of the correlations among the most important dependent variables was also performed. Pearson correlation coefficients (r) were calculated using the SAS CORR Procedure and correlation was considered significant at $P<0.05$. In addition, the average relative frequency of pathogens causing wound decay after 7 weeks incubation was also calculated. Since experiment was a nonsignificant factor in the ANOVA, average data from two experiments are presented for pathogenicity tests.

\section{Results}

Establishment of a specific disease index for ABS infecting 'Rojo Brillante' persimmons. Due to the particular symptomatology of ABS on persimmon fruit, the best choice to assess and quantify this disease on naturally infected fruit is the estimation of the fruit surface showing apparent symptoms, i.e., black spots. This method was first proposed in Israel by Prusky and coworkers, who estimated the area covered by ABS on 'Triumph' persimmons by comparison with a diagrammatic scale depicting different areas covered by the disease (Eshel et al. 2000; Perez et al. 1995). Nevertheless, these diagrams are cultivar-specific and cannot be used in other cultivars because of differences in fruit shape, volume and average dimensions that lead to different percentages of affected area. For instance, if compared with 'Triumph', 'Rojo Brillante' fruit has a different shape and is considerably larger, with broader lateral sides. Therefore, we developed a particular 6-point ABS disease index for 'Rojo Brillante' persimmons based on the quantification of disease severity according to the following objective quantitative scale (Fig. 1): Score $=0$, no disease, no spots present on the peel or under the calyx; 1 , minor or slight disease, few $(<20)$ small spots $(0.5-2 \mathrm{~mm}$ diameter $)$ on the peel or under the calyx, estimated infected area is $0-0.5 \%$ of fruit peel surface; 2, mild or slight-moderate disease, some (20 to 50) small spots $(0.5-2 \mathrm{~mm})$ on the peel or under the calyx, very few (1 to 3 ) medium-sized $(2-5 \mathrm{~mm})$ spots on the peel or under the calyx, estimated infected area is 0.5 to $1 \%$ of fruit peel surface; 3 , moderate disease, abundant (51 to 100$)$ small spots $(0.5-2 \mathrm{~mm}$ diameter) on the peel or under the calyx, few (4 to 10$)$ medium-sized (2-5 $\mathrm{mm}$ ) spots on the peel or under the calyx, very few $(1$ or 2$)$ large $(>10 \mathrm{~mm})$ spots on the peel, continuous small $(5-10 \mathrm{~mm})$ circular spot under the calyx, estimated infected area is 1 to $5 \%$ of fruit peel surface; 4 , intense or moderate-severe disease, very abundant ( $>100)$ small spots $(0.5-2 \mathrm{~mm})$ on the peel or under the calyx, some (11 to 20) mediumsized (2-5 mm) spots on the peel or under the calyx, few (3 to 5) large $(>10 \mathrm{~mm})$ spots on the peel, continuous medium $(10-20 \mathrm{~mm})$ circular spot under the calyx, estimated infected area is 5 to $20 \%$ of fruit peel surface; 5 , severe disease, some $(>20)$ medium-sized $(2-5 \mathrm{~mm})$ spots on the peel or under the calyx, abundant $(>5)$ large $(>10 \mathrm{~mm})$ spots on the peel, continuous large $(>20 \mathrm{~mm})$ circular spot under the calyx, estimated infected area is $>20 \%$ of fruit peel surface. Fruit classified as score 2 or higher were generally considered as nonmarketable in first category persimmon export markets.

Latent disease. Every season, after 2 or 3 weeks of incubation at $25^{\circ} \mathrm{C}$ in humid chambers, most surface-disinfested fruit from both orchards had decay symptoms. Irrespective of the season, the majority of infected 'Rojo Brillante' persimmons (more than 90\%) showed symptoms of ABS caused by A. alternata. Other pathogens that were identified causing postharvest disease in intact fruit were Botrytis cinerea Pers.:Fr., causing gray mold; P. clavispora, L. theobromae, $N$. mediterraneum, and $N$. luteum, causing stem-end rots; and C. gloeosporioides, causing persimmon anthracnose (data not shown).
Most of these pathogens were identified and tested for pathogenicity as described below.

The ABS incidence and index were not significantly different among orchards, so results for each season are presented as means from two orchards (Fig. 2). In general, ABS incidence was higher in 2009 season, with an incidence of 66,83 and $100 \%$ after 1,2 and 3 weeks of incubation at $25^{\circ} \mathrm{C}$, respectively. Likewise, disease development on infected fruit was greater this season, with ABS scores of 3 and 5 after 4 and 6 weeks of incubation (Fig. 2A). In 2010 season, ABS incidence was of 9, 50, 68, 92 and $100 \%$ after $1,2,3,4$ and 5 weeks of incubation, respectively, but the ABS score reached 3 and 5 only after 7 and 9 weeks of incubation, respectively (Fig. 2B). In both seasons, the limit of marketability for first category fruit in export markets (ABS index $\geq 2$ ) was reached after 4 weeks of incubation.

Disease on artificially wounded fruit. Significant interactions between the factors, season and orchard were found for the percentage of infected wounds on artificially wounded 'Rojo Brillante' persimmons. Therefore, disease incidence is presented separately for each level of these factors (orchards 1 and 2, seasons A and B; Figure 3). Irrespective of season and orchard, after 4 weeks of incubation at $20^{\circ} \mathrm{C}$, total incidence of wound infections, i.e., decay caused by all pathogens, ranged from 10 to $20 \%$. After 7 weeks, total incidence increased to about $40 \%$ on fruit from season 1 and about 90 and $70 \%$ on fruit from season 2 and orchards 1 and 2, respectively. This pattern was due to the incidence of disease caused by A. alternata and Penicillium spp., which were the most important causal agents of wound infections. After 7 weeks incubation and considering all data from two orchards and two seasons, correlations were highly significant between total incidence of wound infections and the incidence of disease caused by A. alternata $(P<0.0001)$ and Penicillium spp. $(P<0.0001)$ (Table 1$)$. The relative frequency of infections by these pathogens was highly variable and dependent on both season and orchard. In 2009, the relative frequency of infections on fruit from orchard 1 at the end of the incubation period ( 7 weeks) caused by A. alternata was $50 \%$, Penicillium spp. $33 \%$, and other pathogens $17 \%$. For fruit from orchard 2 the relative frequencies of infections were: A. alternata $60 \%$ and Penicillium spp. $40 \%$ (Fig. 4A). In 2010, these frequencies were: in fruit from orchard 1, A. alternata $39 \%$, Penicillium spp. $55 \%$, and other pathogens $6 \%$; and in fruit from orchard 2, A. alternata 33\% and Penicillium spp. 67\% (Fig. 4B). Rhizopus spp., Trichoderma spp., and especially Cladosporium spp. were other identified pathogens causing decay in artificial persimmon peel wounds.

Disease of commercially handled fruit during cold storage. The incidence of postharvest diseases on commercially handled 'Rojo Brillante' persimmons cold-stored at $1{ }^{\circ} \mathrm{C}$ was significantly dependent on the season but not on the orchard. ABS caused by A. alternata was by far the most prevalent disease during the entire cold storage periods of 10 weeks in 2009 and 20 weeks in 2010. Other pathogens that were isolated from infected fruit during this period were B. cinerea, Penicillium spp., Cladosporium spp., or minor stem-end diseases (data not shown). Irrespective of season and orchard, ABS incidence on 'Rojo Brillante' persimmons cold-stored at $1{ }^{\circ} \mathrm{C}$ was higher than 50 and $80 \%$ after 4 and 6 weeks, respectively (Fig. 5). Nevertheless, infected persimmons were more susceptible to ABS in 2009 than 2010 because ABS incidence and severity were higher at the same evaluation date. For instance, while in 2009 the ABS index was 4.2 after 10 weeks of cold storage and the experiment was hence terminated (Fig. 5A), in 2010 this index was only of 2.2, and it was 4.8 after 20 weeks of storage (Fig. 5B). Furthermore, while in 2009 the limit of marketability for first category persimmons in export markets (ABS index $\geq 2$ ) was reached after 6 weeks of cold storage, it was reached after 10 weeks in 2010 . These differences in fruit susceptibility were in agreement with those observed during the assessment of $\mathrm{ABS}$ in intact persimmons incubated at $25^{\circ} \mathrm{C}$ for 9 weeks.

Identification, pathogenicity and disease development. All the fungal species that have been cited in previous sections were isolated into pure culture and identified, depending on genus, by different 
means. Isolates of B. cinerea, Rhizopus spp. and Trichoderma spp. were identified in our IVIA laboratory on the basis of macroscopic and/or microscopic morphology. The most common Penicillium spp. and Cladosporium spp. isolated from infected persimmons were identified in the specialized laboratories as $P$. expansum and C. cladosporioides, respectively. Other isolates identified by CECT or IVAMI on the basis of morphology and DNA sequencing include A. alternata, L. theobromae, N. mediterraneum, N. luteum, C. gloeosporioides, and P. clavispora.

In the pathogenicity tests with 'Rojo Brillante' persimmons, Koch's postulates were satisfactorily fulfilled with all fungal isolates tested. In trials with fungi inoculated with PDA mycelial plugs, disease incidence on persimmons inoculated with all five fungal species was $100 \%$ after 4 days of incubation at $20^{\circ} \mathrm{C}$. Severity (lesion size) of disease caused by $L$. theobromae, $N$. mediterraneum, $N$. luteum, C. gloeosporioides, and P. clavispora after 12 days of incubation at $20^{\circ} \mathrm{C}$ was $53,46,30,35$, and $25 \mathrm{~mm}$, respectively (Fig. 6). All these pathogens were able to grow, although very slowly, in persimmons stored at $5^{\circ} \mathrm{C}$. After 75 days of storage at this temperature, disease incidence and severity were: $L$. theobromae $75 \%$ and $23 \mathrm{~mm}$ in diameter, N. mediterraneum $100 \%$ and $36 \mathrm{~mm}$, N. luteum $100 \%$ and $25 \mathrm{~mm}$, and C. gloeosporioides $94 \%$ and $19 \mathrm{~mm}$. In the case of $P$. clavispora, the evaluations ended after 39 days at $5^{\circ} \mathrm{C}$, at which time disease incidence and severity were $100 \%$ and $13 \mathrm{~mm}$, respectively (Fig. 6). In pathogenicity trials with fungi inoculated with spore suspensions, all three species tested caused 100\% disease after 10 days of incubation at $20^{\circ} \mathrm{C}$. After 14 days, lesions caused by $C$. cladosporioides, $A$. alternata and $P$. expansum were approximately 7, 5, and $28 \mathrm{~mm}$ in diameter, respectively (Fig. 7). In in vivo tests at $5^{\circ} \mathrm{C}$, all three fungi grew and caused disease, particularly $P$. expansum, with average disease incidence after 42 days of $100 \%$ and a lesion diameter of $30 \mathrm{~mm}$. At this time, lesions of C. cladosporioides and A. alternata were 14 and $9 \mathrm{~mm}$ in diameter, respectively (Fig. 7).

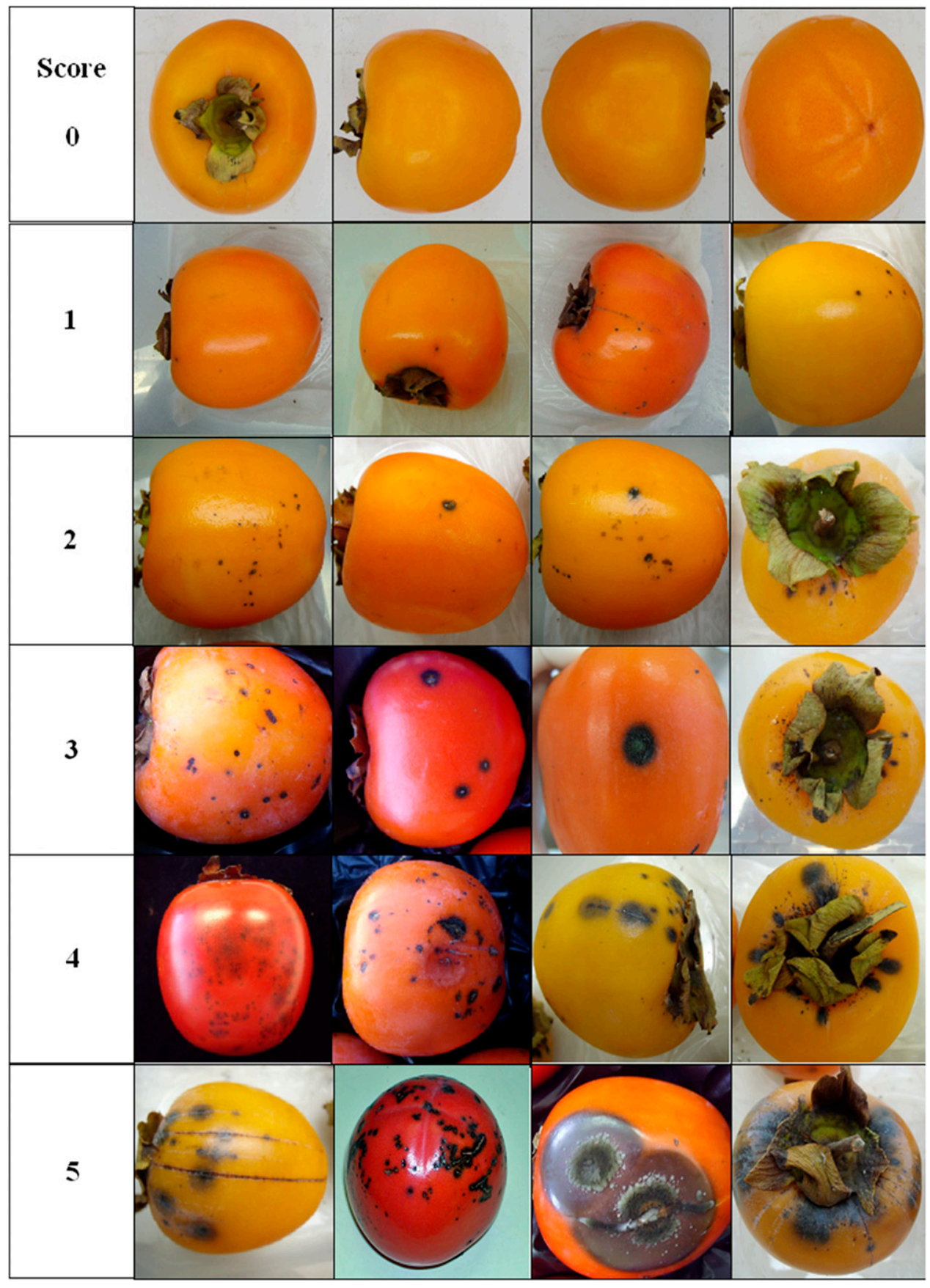

Fig. 1. Photographs of the alternaria black spot (ABS) severity index specifically developed for 'Rojo Brillante' persimmons. 
In most cases, once the fungus was verified to be pathogenic in persimmon, it was included in the IVIA CTP collection of postharvest pathogens and representative nucleotide sequences of the isolate were deposited in GenBank (viz: accession numbers for

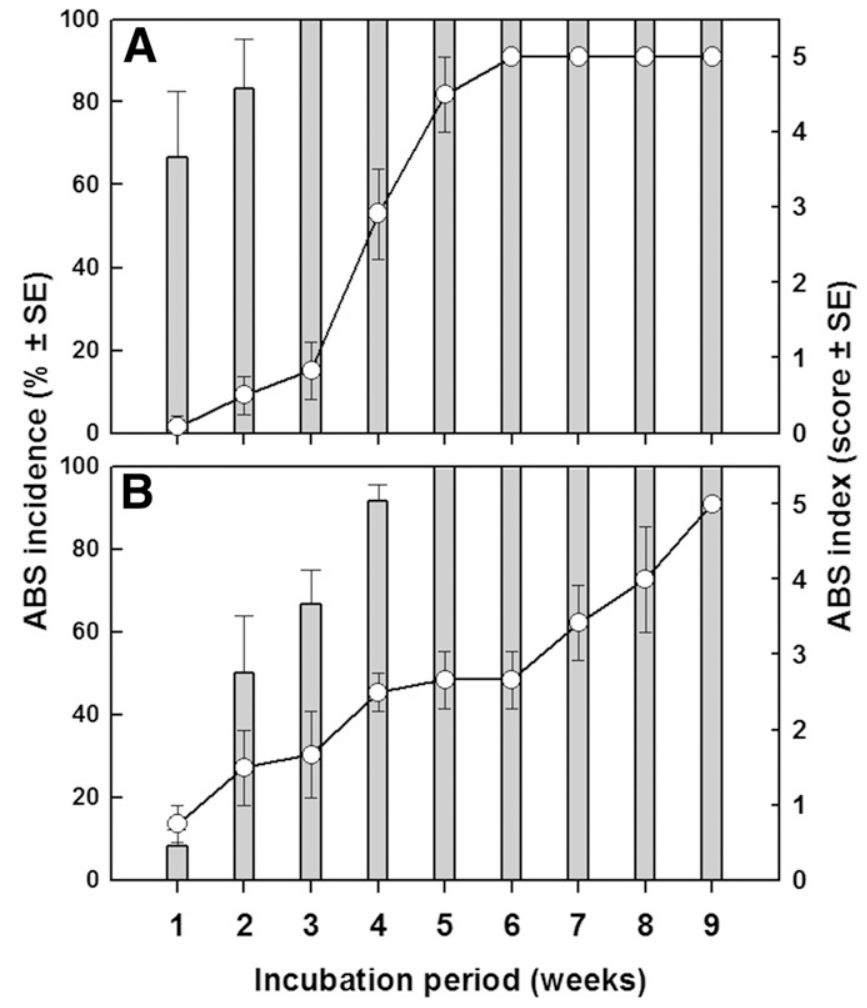

Fig. 2. Incidence (bars) and disease index (lines) of alternaria black spot (ABS) on intact 'Rojo Brillante' persimmons harvested from two orchards and incubated in humid chambers at $20^{\circ} \mathrm{C}$ for 9 weeks. Data from two seasons, 2009 (A) and 2010 (B). isolates of L. theobromae, $N$. mediterraneum, $N$. luteum, and C. gloeosporioides were JX997744, JX997745, JX997746, and KC113600, respectively). Since some of these fungi were reported for the first time to be pathogenic in persimmon in Spain or worldwide, disease notes or brief reports have been published (Palou et al. 2012, 2013a, b). In the case of A. alternata, L. theobromae, N. mediterraneum, and $N$. luteum, color photographs showing the symptoms of postharvest disease caused by these pathogens in 'Rojo Brillante' persimmons can be found in these citations. In the case of $P$. expansum, $C$. cladosporioides, $P$. clavispora and $C$. gloeosporioides, such symptoms after artificial inoculation and incubation for 14 or 18 days at $20^{\circ} \mathrm{C}$ are shown in Figure 8 .

\section{Discussion}

The present study indicated that ABS, caused by A. alternata, is by a considerable margin the most important postharvest disease of sweet persimmon cv. Rojo Brillante in the València region and consequently in Spain. Irrespective of season and orchard, ABS was the most frequently observed disease in fruit used for assessment of latent and wound infections and in commercially handled and cold-stored persimmons. This was corroborated by local industry observations. In recent seasons, substantial postharvest losses (up to $30 \%$ of fruit) due to apparent peel black spots, caused mainly by

Table 1. Correlations of the incidence of postharvest diseases on 'Rojo Brillante' persimmons artificially wounded and incubated in humid chambers at $20^{\circ} \mathrm{C}$ for 7 weeks

\begin{tabular}{lcr}
\hline & \multicolumn{2}{c}{ Correlation } \\
\cline { 2 - 3 } Pair of variables $^{\mathbf{a}}$ & $\mathbf{r}^{\mathbf{b}}$ & \multicolumn{1}{c}{$\boldsymbol{P}$} \\
\hline Aa - Total & 0.7013 & $<0.0001$ \\
Peni - Total & 0.8807 & $<0.0001$ \\
Aa - Peni & 0.5199 & 0.0023 \\
\hline
\end{tabular}

a Variables are the incidence of disease (percentage of infected wounds) caused by Alternaria alternata (Aa), Penicillium spp. (Peni), and all pathogens (Total). Data from two seasons and two orchards.

b Pearson's correlation coefficient.

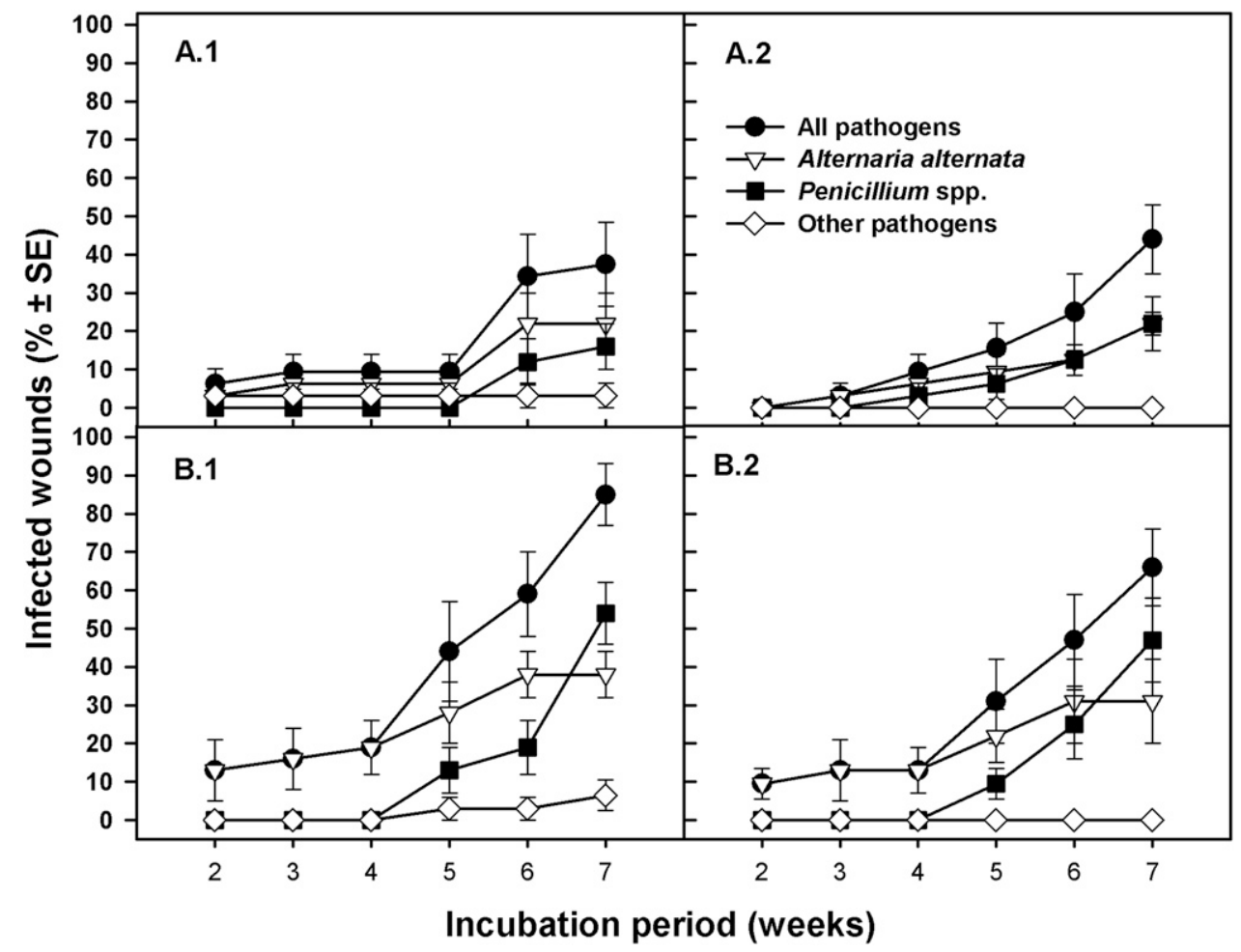

Fig. 3. Incidence of postharvest diseases from wound infections on 'Rojo Brillante' persimmons from two orchards (1 and 2), artificially wounded and incubated in humid chambers at $20^{\circ} \mathrm{C}$ for 7 weeks. Data from two seasons, 2009 (A) and 2010 (B). 
A. alternata, have been observed on 'Rojo Brillante' persimmons cold-stored in commercial packinghouses in the València area (Palou et al. 2012). Packinghouse managers confirmed that after the implementation of postharvest 1-MCP treatments to maintain fruit firmness and reduce chilling injury, the high incidence of ABS is currently the main factor limiting prolonged cold storage of 'Rojo Brillante' persimmons. As persimmon planted area and fruit production increased recently in Spain, the volumes of fruit subjected to cold storage are also increasing to extend the commercialization period in current markets and reach new, more distant markets. Therefore, the incidence of ABS and consequent economic losses are also rising considerably.

The first studies on persimmon ABS were conducted in Israel (Prusky et al. 1981a), followed by other reports (Snowdon 1990), and later the disease was described in other persimmon-producing countries like South Korea (Kwon et al. 2004a; Park et al. 1997), Brazil (Cia et al. 2003) or Turkey (Kurt et al. 2010) affecting astringent (e.g., 'Triumph') and nonastringent (e.g., 'Fuyu') cultivars. Researchers in Israel observed that large produce losses after cold storage of 'Triumph' and 'Fuyu' were due to black spots of different sizes and shapes located under the sepals or at any point on the fruit surface (Prusky et al. 1981a). It was initially thought that the damage was a physiological disorder that could be reduced by preserving the fruit in controlled atmospheres with high levels of carbon dioxide $\left(\mathrm{CO}_{2}\right)$ (Guelfat-Reich and Ben-Arie 1975). Nevertheless, it was later demonstrated that the spots were caused by field infections by $A$. alternata that only produced visible symptoms after harvest. Two different primary modes of infection were described: either through small wounds under the sepals attached to the fruit stem and/or directly into the fruit cuticle (Prusky et al. 1981a). Typically these infections remained quiescent until harvest, developed slightly during storage at $1{ }^{\circ} \mathrm{C}$ and expanded further during fruit shelf-life or commercialization. In addition, when the conditions before harvest were especially wet or rainy, the incidence of postharvest ABS increased due to active infections initiated in peel wounds, which considerably reduced the storability of persimmons at low temperature (Kobiler et al. 2011). Further research showed that ABS incidence was higher in the stem end than in the stylar end of 'Triumph' persimmons because of the absence of peel cracks and lower maturity of the tissues in the latter (Biton et al. 2014b).

These findings are in agreement with the high incidence of ABS observed in our assessment of wound pathogens. This incidence was positively correlated with total incidence of decay in wounds and also, although to a lesser extent, with the incidence of decay caused in wounds by Penicillium spp., which are known to be strict wound pathogens of fresh fruits. Therefore, inoculum of A. alternata was naturally present on the surface of persimmons at the time of harvest and was able to successfully infect peel wounds inflicted to commercially mature fruit. Similarly to the mentioned case of 'Triumph' in Israel, the total of postharvest ABS incidence in 'Rojo Brillante' persimmons is not only due to latent infections produced during early stages of fruit growth, but also to active infections that take place in peel wounds inflicted by any means before harvest (insects, physiological cracking, etc.), during harvest, and even after harvest (transportation, packinghouse handling, etc.). Depending on many different weather and production factors, the relative proportion of postharvest ABS due to each type of infection varies. In this study, multifactorial ANOVAs showed that, in general, season was a considerably greater source of variation than the orchard. This was not surprising, considering the general uniformity of the Ribera Alta persimmon-growing area in terms of orography, topography and soil characteristics, and the similarity of the two orchards studied in tree age and planting pattern. Considering this starting point, we have initiated, in collaboration with colleagues from the 'IVIA Centre de Protecció Vegetal i Biotecnologia' (IVIA-CPVB), epidemiological studies to determine the periods of production and dispersal of inoculum of A. alternata in 'Rojo Brillante' persimmon orchards in our production area and establish potential correlations between actual postharvest disease incidence, inoculum dynamics and environmental conditions. Obviously, the final purpose is to define the optimal timing in our conditions for the application of field fungicide treatments to reduce inoculum levels and protect the fruit.

Alternaria alternata is a very polyphagous fungus that attacks a large number of hosts, including many fruit trees. It is the most frequently reported Alternaria species in the literature and includes

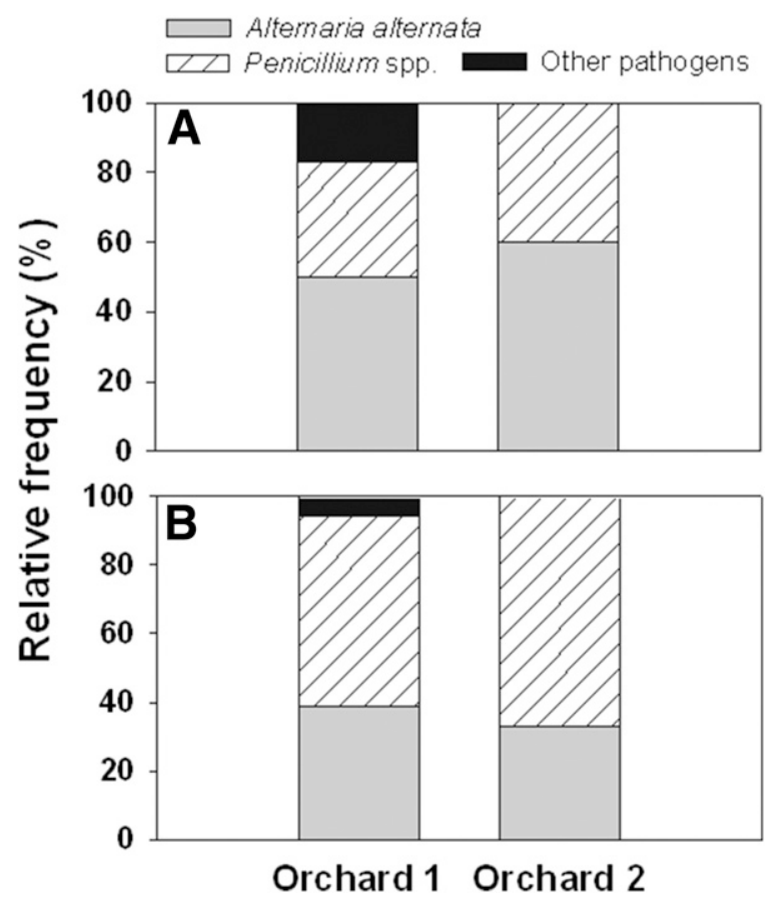

Fig. 4. Relative frequency of pathogens causing postharvest diseases on 'Rojo Brillante' persimmons from two orchards. The fruit were artificially wounded and incubated in humid chambers at $20^{\circ} \mathrm{C}$ for 7 weeks. Data from two seasons, 2009 and 2010 (A and B).

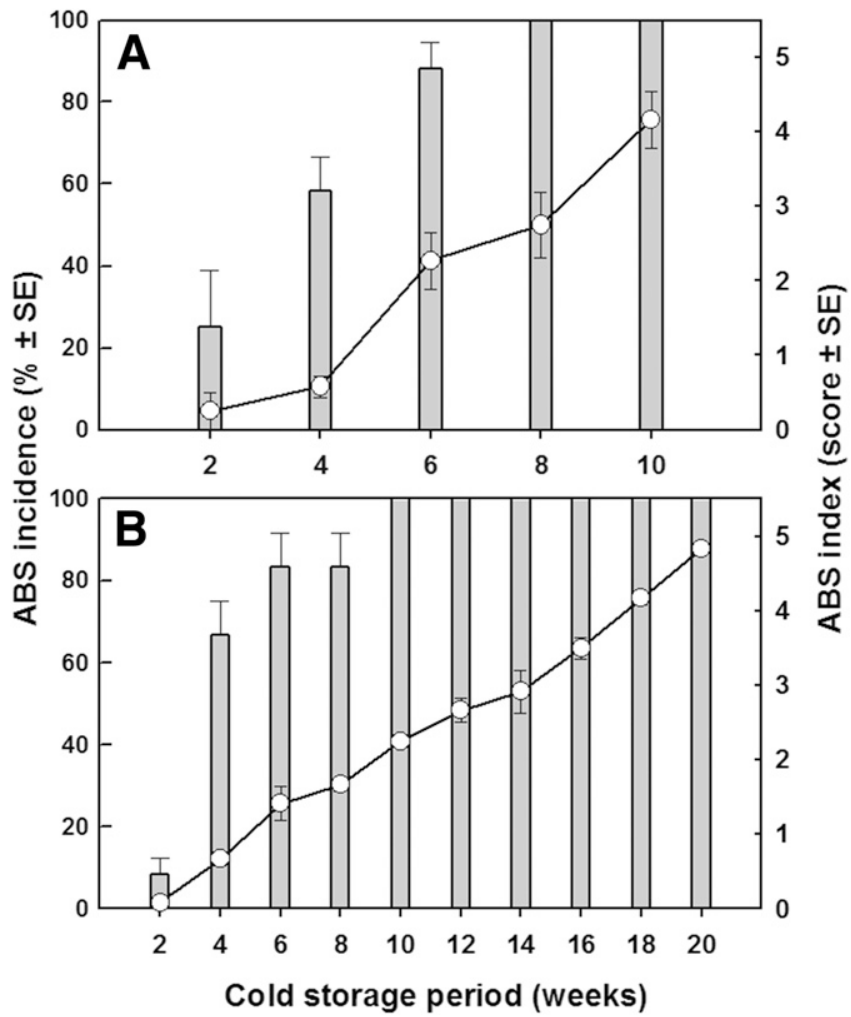

Fig. 5. Incidence (bars) and disease index (lines) of alternaria black spot (ABS) on commercially handled 'Rojo Brillante' persimmons from two orchards stored at $1^{\circ} \mathrm{C}$ and $90 \%$ RH for 10 or 20 weeks. Data from two seasons, 2009 (A) and 2010 (B). 


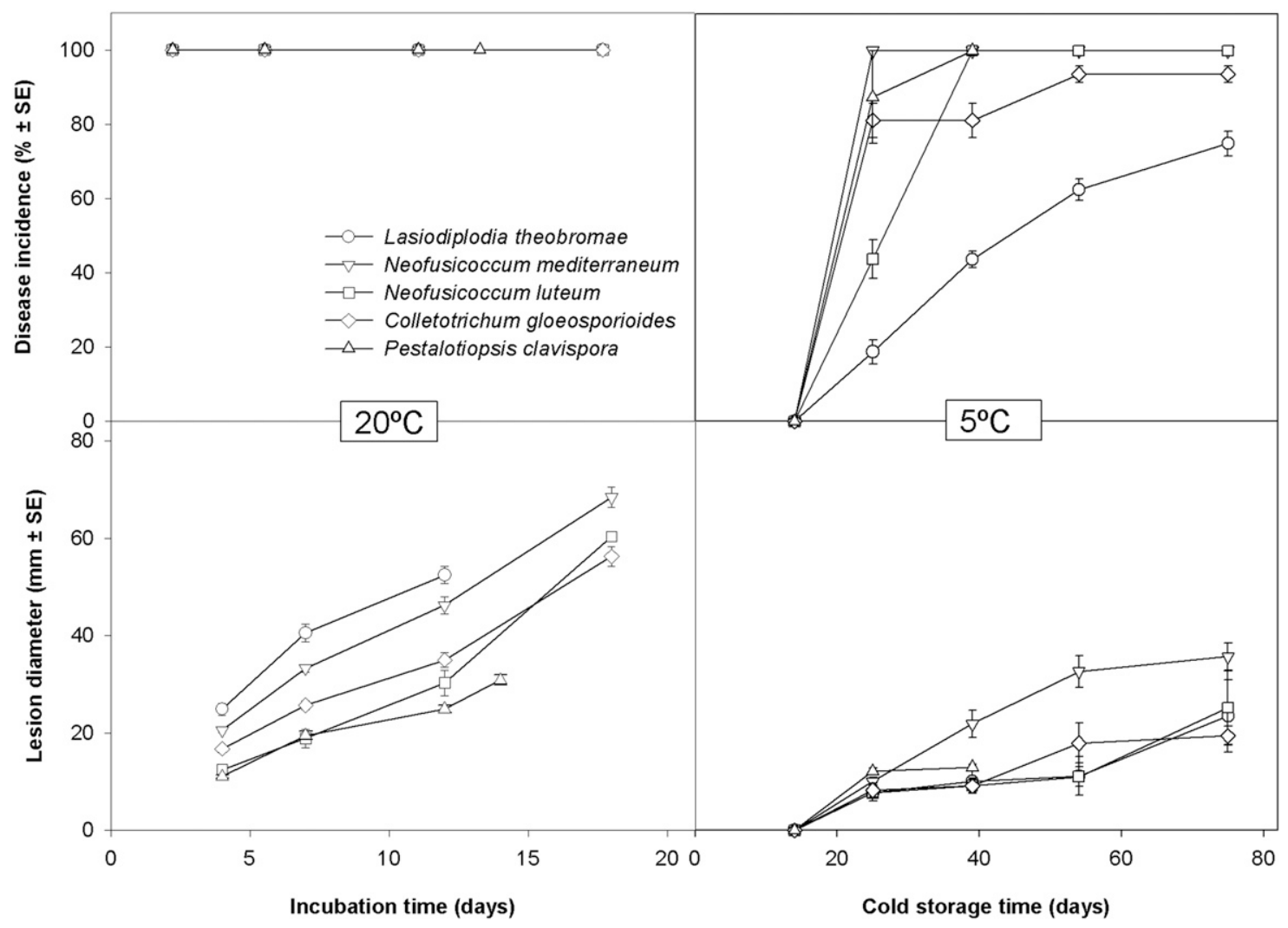

Fig. 6. Incidence and severity of disease caused by different pathogens on 'Rojo Brillante' persimmons artificially inoculated with PDA mycelial plugs and incubated at $20^{\circ} \mathrm{C}$ for up to 18 days or stored at $5^{\circ} \mathrm{C}$ for 75 days.

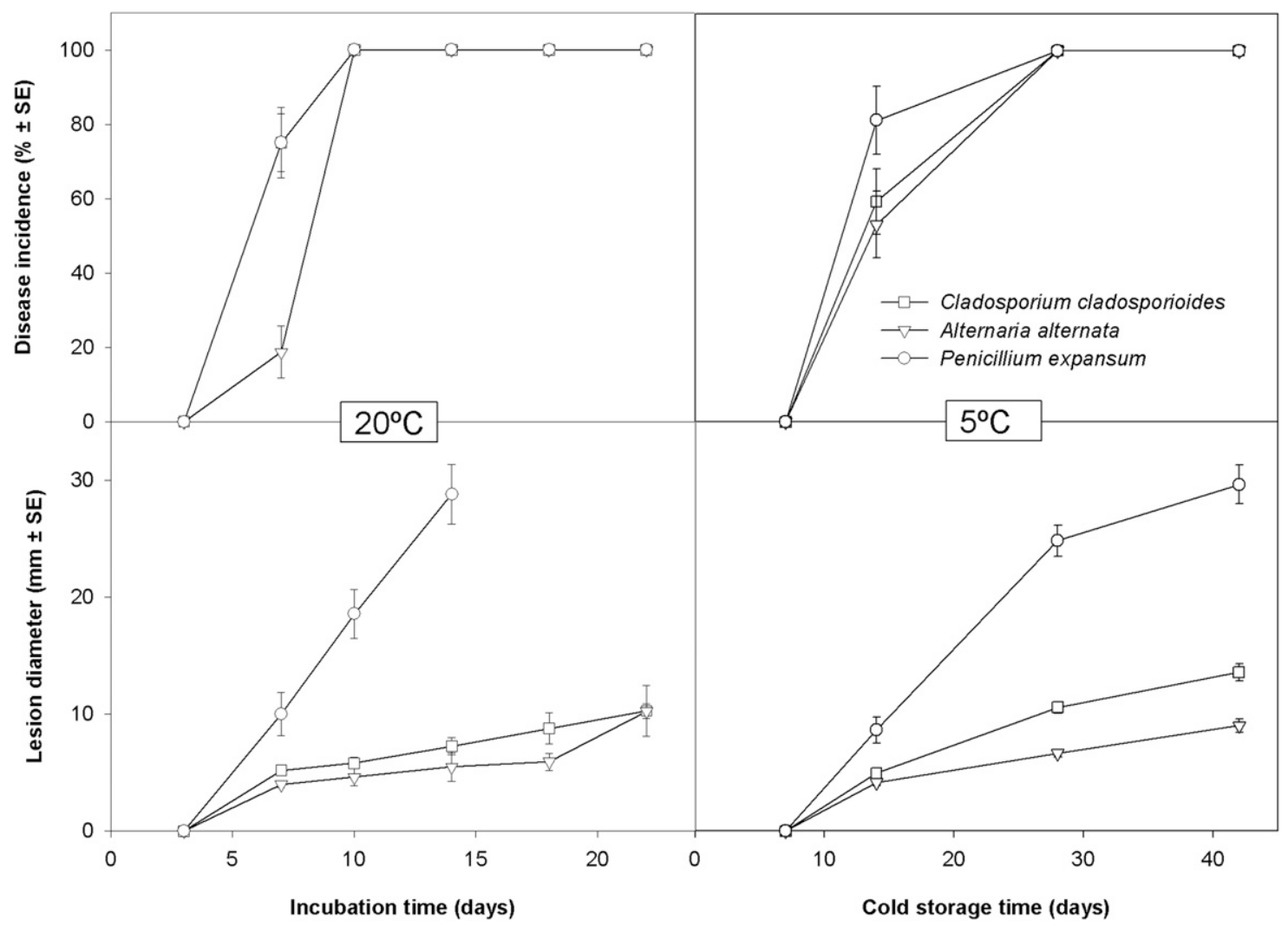

Fig. 7. Incidence and severity of disease caused by different pathogens on 'Rojo Brillante' persimmons wound inoculated with spore suspensions and incubated at $20^{\circ} \mathrm{C}$ for up to 22 days or stored at $5^{\circ} \mathrm{C}$ for 42 days. 
saprophytes, epiphytes on plant foliage, parasites on live plants and, occasionally, even on animals and humans. It is also the most frequent pathogen of stored horticultural produce and includes several strains that produce host-specific toxins. Other strains produce non-host-specific toxins such as tenuazonic acid, altertoxin or alternariol methyl ether. In the case of strains pathogenic to fruit, under field conditions, they survive and develop saprophytically in rotting or dead organic matter, leaves, buds, and also on the ground. Typically, conidia are profusely produced and easily dispersed by wind and rain, reaching flowers, immature growing fruit, or mature fruit and potentially causing both latent and wound infections (Rotem 1998). Prusky et al. (1981a) described at length the symptoms of these infections on persimmon fruit cv. Triumph and developed a method for preharvest assessment of latent infections (Prusky et al. 1981b). After harvest, the fungus is able to germinate and grow, although very slowly, even at temperatures close to $0^{\circ} \mathrm{C}$, provided that humidity is high. In this work, for instance, the diameter of lesions caused by A. alternata on 'Rojo Brillante' persimmons artificially inoculated and stored at $5^{\circ} \mathrm{C}$ was $0,4,7$, and $9 \mathrm{~mm}$ after 7 , 14,28 , and 42 days, respectively, which represents a daily increase of lesion size at $5^{\circ} \mathrm{C}$ of about $0.2 \mathrm{~mm}$. Consequently, it is common that ABS decay symptoms enlarge after harvest and particularly during commercial cold storage. Thus, the best option to assess disease severity during or after storage is to quantify the percentage of the fruit surface area with black spots (Perez et al. 1995), which is cultivar dependent. For this reason, we have developed the ABS index specific for 'Rojo Brillante' persimmons previously described and presented graphically in Figure 1. This index has been published in Spanish (Palou and Taberner 2014) and, as part of a persimmon extension book chapter (Vicent et al. 2015), has been widely distributed to the persimmon industry to help in assessing the disease under commercial conditions. The index is also a very good tool to determine the influence on the incidence of ABS on 'Rojo Brillante' persimmons on the adoption of postharvest technologies such as $\mathrm{CO}_{2}$ deastringency, cold storage, 1-MCP treatment, or different sequences of application of these handling procedures. Furthermore, it is also extremely useful to evaluate the effectiveness of disease control treatments of different natures that are currently under experimentation on naturally infected persimmons.

Since ABS is a postharvest disease caused by field latent infections, near-harvest wound infections or in cold storage, satisfactory decay control should be pursued through the implementation of complementary field and postharvest treatments (Kobiler et al. 2011). Antifungal field treatments can be addressed to either induction of fruit resistance to fungal infection and/or subsequent disease development, as the application of growth regulators such as gibberellin or benzyladenine (Biton et al. 2014a; Eshel et al. 2000), or the protection against and/or the eradication of pathogenic infections. The latter can be preventive fungicide treatments to suppress the production and/or dispersion of fungal inoculum, or curative fungicide treatments that inhibit the development of infections already established in the fruit. In this case, it is common that these fungicides (e.g., iprodione; Perez et al. 1995) are applied before harvest because market regulations do not allow their use as postharvest treatments (Kobiler et al. 2011). Postharvest treatments that have proven somewhat effective in reducing ABS incidence on 'Triumph' persimmons in Israel include: fruit exposure to modified atmospheres with levels of $30 \% \mathrm{CO}_{2} ; 30$-s dips at room temperature in aqueous solutions of sodium troclosene (1,3-dichloro-1,3,5-triazine-4,4,6 trione) at $500 \mathrm{mg} / \mathrm{L}$ ); 30-s dips in hydrochloric acid solutions at $50 \mathrm{mM}$, alone or mixed with prochloraz at $45 \mathrm{~g} / \mathrm{L}$ at room temperature; combination of sodium troclosene dips with subsequent application of this product in cold storage rooms as a fumigant or as a spray in the packingline after cold storage (Kobiler et al. 2011; Prusky et al. 1997, 2001, 2006). At present, there are no antifungal products registered in Spain for postharvest application on persimmon fruit.

Besides decay caused by A. alternata, other pathogens causing postharvest disease on 'Rojo Brillante' persimmons were isolated
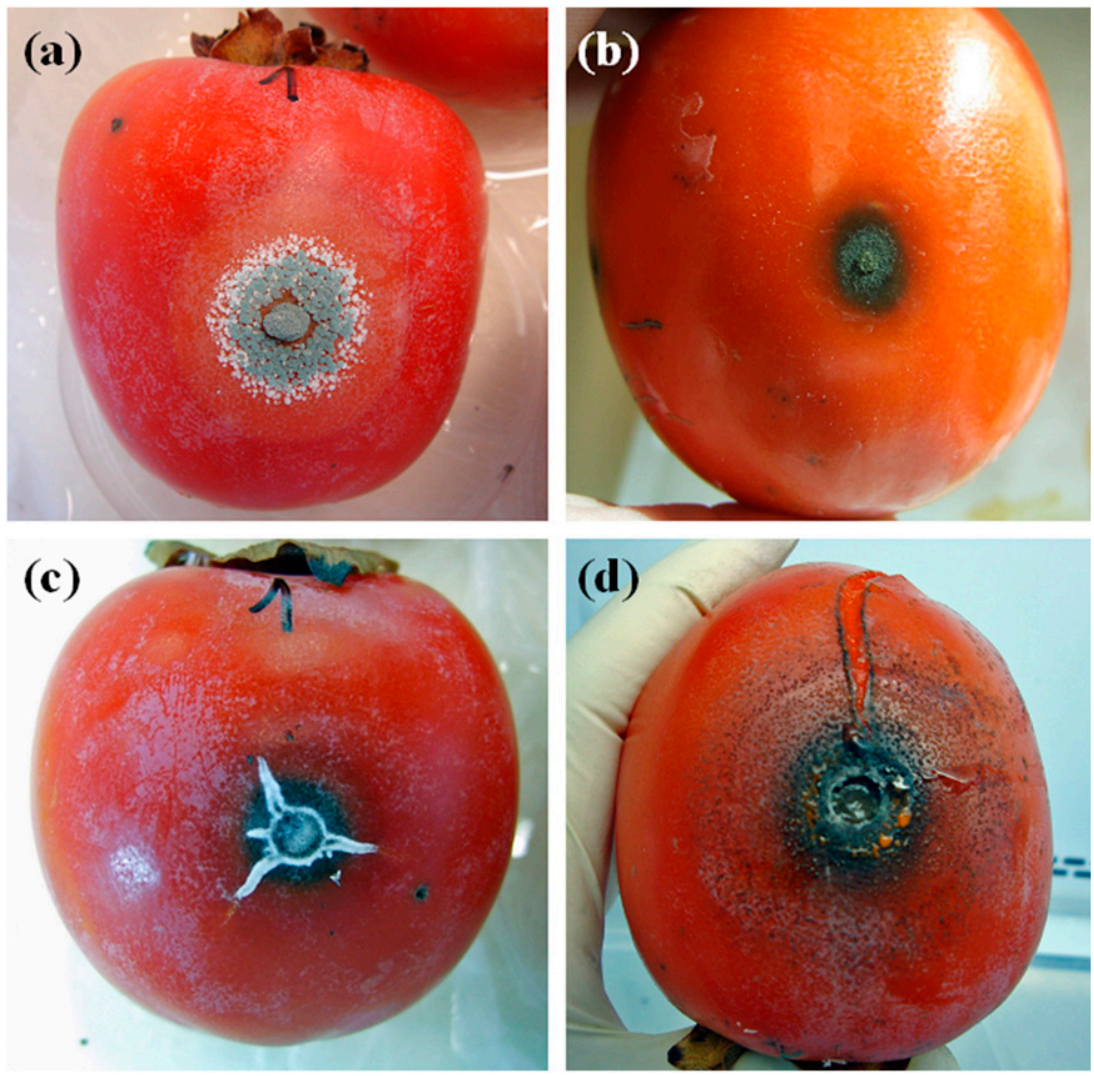

Fig. 8. Disease symptoms caused by Penicillium expansum (a), Cladosporium cladosporioides (b) and Pestalotiopsis clavispora (c) on artificially inoculated 'Rojo Brillante' persimmons incubated at $20^{\circ} \mathrm{C}$ for 14 days, and by Colletotrichum gloeosporioides (d) on fruit incubated at $20^{\circ} \mathrm{C}$ for 18 days. 
in this study, identified and characterized in terms of pathogenicity and disease development. Among those isolated from latent infections, the most frequent were $B$. cinerea causing gray mold; $P$. clavispora, $L$. theobromae, $N$. mediterraneum, and $N$. luteum, causing stem-end rots; and C. gloeosporioides, causing persimmon anthracnose. All of them were pathogenic and able to grow, although slowly, at $5^{\circ} \mathrm{C}$. Further studies under local conditions would be necessary to characterize the epidemiology and incidence of disease caused by each of these pathogens (inoculum distribution in the field, prevalent infection site, time and conditions of infection, etc.). As with other postharvest decays caused by these pathogenic fungi on other fruit species, disease incidence on persimmons will presumably be higher in seasons with abundant rain and humid weather because, in general, these pathogens require high humidity for inoculum production and dispersal and subsequent fruit infection and disease development (Barkai-Golan 2001). Infections of B. cinerea have been reported on persimmon leaves or fruit in Israel (Barkai-Golan 2001), California (Ogawa and English 1991) or Korea (Kwon et al. 1999). In New Zealand, a cosmetic disorder of persimmon fruit consisting of dark brown, corky spots on the skin and known as scarring was found to be directly related with field infections by $B$. cinerea (Rheinländer et al. 2013). In the present work, postharvest decay symptoms caused by $P$. clavispora on 'Rojo Brillante' persimmons were mainly observed in the fruit stem-end. Dry black spots initiated under the sepals in the calyx and spread throughout the stem-end area until numerous fruiting bodies (acervuli) appeared and cottony white fungal mycelium developed in the central area of the lesion. On few occasions infections also occurred in other parts of the fruit surface. Pestalotia diospyri Syd. \& P. Syd. [syn. Pestalotiopsis diospyri (Syd. \& P. Syd.) Rib. Souza] causing necrotic spots in the calyx of 'Triumph' persimmons has been reported in Spain (Blanco et al. 2008). The same pathogen had been reported previously in New Zealand (Goh et al. 1991). In Japan, other Pestalotiopsis spp. that have been described as the causal agents of stem-end rots on persimmon fruit include $P$. longiseta (Speg.) K. Dai \& Ts. Kobay. and P. foedans (Sacc. \& Ellis) Steyaert (Taguchi et al. 2001). With reference to the described postharvest decay caused on 'Rojo Brillante' persimmons by L. theobromae, $N$. mediterraneum, $N$. luteum and $C$. gloeosporioides, further information can be found in previously published notes (Palou et al. 2013a, b). Different Colletotrichum spp., including C. gloeosporioides (Kwon et al. 2000; Mendes et al. 1998; Zhang and $\mathrm{Hu}$ 2004), C. acutatum J. H. Simmonds (Kwon and Kim 2011; Williamson and Sutton 2010), and C. horii B. Weir \& P.R. Johnst. (Kwon et al. 2013; Xie et al. 2010; Yu et al. 2013) have been reported as the cause of persimmon anthracnose in producing areas such as Korea, China, Japan, Brazil, USA or New Zealand. However, C. horii, formerly known as Gloeosporium kaki Hori, is considered as a distinct group within the $C$. gloeosporioides sensu lato species complex (Weir and Johnston 2010).

Besides $A$. alternata, the most frequent pathogens isolated in this work from wound infections of 'Rojo Brillante' persimmons were $P$. expansum and C. cladosporiodes. Penicillium expansum is a common strict wound pathogen that has been proven to cause postharvest blue mold on many fruits, including all pome and stone fruits (Barkai-Golan 2001; Snowdon 1990). On persimmons, it has been cited as pathogenic in South Korea (Kwon et al. 2006), along with Penicillium crustosum Thom (Kwon and Park 2003a). Cladosporium spp. and particularly $C$. cladosporiodes are ubiquitous fungi, very abundant in fields and packinghouses. However, their pathogenicity is generally low and typically affect senescent or overripe fruits producing small superficial, black or dark-green lesions, which in some cases might be confused with black spots caused by A. alternata. In South Korea, C. cladosporiodes has also been found to be pathogenic and cause postharvest decay (sooty mold) on persimmons (Kwon and Park 2003b).

Other fungal species that were not isolated or were only occasionally found in the present study with 'Rojo Brillante' persimmons, but have been reported as pathogenic on sweet persimmons include Rhizopus spp., Mucor spp., Phoma spp., Phomopsis spp., Fusicoccum spp., Fusarium spp., or Phacidiopycnis washingtonensis CL
Xiao \& J.D. Rogers (Cia et al. 2003; Crisosto 1999; Garibaldi et al. 2010; Goh et al. 1991; Kwon et al. 2004b; Raj and Rana 1987). Furthermore, fungi like Zygophiala jamaicensis EW Mason, Zygophiala wisconsinensis Batzer \& Crous or Dissoconium spp. (Gleason et al. 2011; Kwon et al. 2012; Nasu et al. 1985) have been reported as causal agents of sooty blotch and flyspeck of persimmon fruit, a cosmetic disease whose symptoms are numerous tiny blackish circular spots distributed over large areas of the fruit that do not affect the fruit flesh but cause economic losses because of the negative impact on appearance.

\section{Acknowledgments}

This research was partially funded by the Spanish 'Ministerio de Ciencia e Innovación' (MICINN; project AGL2004-05271/AGR) and the European Union (FEDER Program). We thank Mario Vendrell and Canso Coop. V. (L'Alcudia, València, Spain) and Rafael Perucho and 'Consell Regulador de la Denominació d'Origen Kaki Ribera del Xúquer' (L'Alcudia, València, Spain) for kindly providing fruit and technical assistance.

\section{Literature Cited}

Arnal, L., and del Río, M. A. 2003. Removing astringency by carbon dioxide and nitrogen enriched atmospheres in persimmon fruit cv. 'Rojo brillante'. J. Food Sci. 68:1516-1518.

Arnal, L., and del Río, M. A. 2004. Effect of cold storage and removal astringency on quality of persimmon fruit (Diospyros kaki L.) cv. Rojo Brillante. Food Sci. Technol. Int. 10:179-185

Barkai-Golan, R. 2001. Postharvest Diseases of Fruit and Vegetables. Elsevier Science B. V., Amsterdam, The Netherlands. 418 pp.

Ben-Arie, R., Ohad, N., Alla, Z., Assya, G., and Adi, S. N. 2001. Extending the shelflife of 'Triumph' persimmons after storage with 1-MCP. Alon-Hanotea 55: 524-527.

Besada, C., Arnal, L., and Salvador, A. 2008a. Improving storability of persimmon cv. Rojo Brillante by combined use of preharvest and postharvest treatments. Postharvest Biol. Technol. 50:169-175.

Besada, C., Novillo, P., Navarro, P., and Salvador, A. 2014. Effect of a low oxygen atmosphere combined with 1-MCP pretreatment on preserving the quality of 'Rojo Brillante' and 'Triumph' persimmon during cold storage. Scientia Hortic. 179:51-58.

Besada, C., Salvador, A., Arnal, L., and Martínez-Javega, J. M. 2008b. Hot water treatment for chilling injury reduction of astringent 'Rojo Brillante' persimmon at different maturity stages. HortScience 43:2120-2123.

Biton, E., Kobiler, I., Feygenberg, O., Yaari, M., Friedman, H., and Prusky, D. 2014a. Control of alternaria black spot in persimmon fruit by a mixture of gibberellin and benzyl adenine, and its mode of action. Postharvest Biol. Technol. 94:82-88

Biton, E., Kobiler, I., Feygenberg, O., Yaari, M., Kaplunov, T., Ackerman, M., Friedman, H., and Prusky, D. 2014b. The mechanism of differential susceptibility to alternaria black spot, caused by Alternaria alternata, of stem- and bottom-end tissues of persimmon fruit. Postharvest Biol. Technol. 94:74-81.

Blanco, C., Romero, F., and De los Santos, B. 2008. First report of Pestalotiopsis dyospiri causing calyx blight of sweet persimmon in Huelva province (Southwestern Spain). Plant Dis. 92:176-176.

Cia, P., Benato, E. A., Sigrist, J. M., Sarantopoulos, C., Oliveira, L. M., and Padula, M. 2003. In vitro effect of modified atmosphere on mycelial growth of persimmon pathogens and on the control of Rhizopus rot in 'Fuyu' Summa Phytopathol. 29:266-274.

Crisosto, C. H. 1999. Persimmon Postharvest Quality Maintenance Guidelines. Kearney Agricultural Research and Extension Center, DANR, University of California. Online publication. http://kare.ucanr.edu/files/123828.pdf

Eshel, D., Ben-Arie, R., Dinoor, A., and Prusky, D. 2000. Resistance of gibberellin-treated persimmon fruit to Alternaria alternata arises from the reduced ability of the fungus to produce endo-1,4-beta-glucanase. Phytopathology 90:1256-1262.

ESYRCE, 2014. Encuesta sobre superficies y rendimientos de cultivo. Ministerio de Agricultura, Alimentación y Medio Ambiente, MAGRAMA, Madrid, Spain Retrieved 14 January 2015 from http://www.magrama.gob.es/es/estadistica/temas/ estadisticas-agrarias/agricultura/esyrce/ (In Spanish).

Garibaldi, A., Bertetti, D., Amatulli, M. T., and Gullino, M. L. 2010. First report of postharvest fruit rot in persimmon caused by Phacidiopycnis washingtonensis in Italy. Plant Dis. 94:788.

Gleason, M. L., Batzer, J. C., Sun, G., Zhang, R., Diaz Arias, M. M., Sutton, T. B., Crous, P. W., Ivanovic, M., McManus, P. S., Cooley, D. R., Mayr, U., Weber, R. W. S., Yoder, K. S., Del Ponte, E. M., Biggs, A. R. and Oertel, B. 2011. A new view of sooty blotch and flyspeck. Plant Dis. 95:368-383.

Goh, H. H., Lyons, S. N., and Mowat, A. W. 1991. Preliminary observations of diseases on persimmon (Diospyros kaki) and their potential effect on fruit quality. Proc. 44th N.Z. Weed Pest Control Conf.:265-267.

Guelfat-Reich, S., and Ben-Arie, R. 1975. Controlled atmosphere storage of Triumph persimmons. Suppl. Bull. Int. Inst. Refrig. 1:119-123. 
Kobiler, I., Akerman, M., Huberman, L., and Prusky, D. 2011. Integration of preand postharvest treatments for the control of black spot caused by Alternaria alternata in stored persimmon fruit. Postharvest Biol. Technol. 59:166-171.

Kurt, S., Soylu, E. M., and Soylu, S. 2010. First report of black spot disease caused by Alternaria alternata in persimmon fruits in Turkey. Plant Dis. 94:1069.

Kwon, J. H., Ahn, G. H., and Park, C. S. 2004a. Black spot of sweet persimmon (Diospyros kaki) caused by Alternaria alternata. Res. Plant Dis. 10:183-187 (in Korean with English summary).

Kwon, J. H., Ahn, G. H., and Park, C. S. 2004b. Fruit soft rot of sweet persimmon caused by Mucor piriformis in Korea. Mycobiology 32:98-101.

Kwon, J. H., Jeong, S. G., Hong, S. B., Chae, Y. S., and Park, C. S. 2006. Occurrence of blue mold on sweet persimmon (Diospyros kaki) caused by Penicillium expansum. Res. Plant Dis. 12:290-293 (in Korean with English summary).

Kwon, J. H., Kang, S. W., and Park, C. S. 1999. Persimmon gray mold caused by Botrytis cinerea. Plant Dis. Agric. 5:55-57 (in Korean with English summary).

Kwon, J. H., Kang, S. W., and Park, C. S. 2000. Cultural characteristics of Colletotrichum gloeosporioides causing anthracnose of persimmon. Res. Plant Dis. 6:48-50 (in Korean with English summary).

Kwon, J. H., and Kim, J. 2011. First report of fruit black spot of Diospyros kaki caused by Colletotrichum acutatum in Korea. Plant Pathol. J. 27:100.

Kwon, J. H., Kim, J., Choi, O., Gang, G. H., Han, S., and Kwak, Y. S. 2013. Anthracnose caused by Colletotrichum horii on sweet persimmon in Korea: dissemination of conidia and disease development. J. Phytopathol. 161:497-502.

Kwon, J. H., Kim, J., Choi, O., Gang, G. H., and Kawak, Y. S. 2012. Occurrence of sooty blotch and flyspeck disease on sweet persimmon in Korea. Mycobiology 40:210-213.

Kwon, J. H., and Park, C. S. 2003a. Blue mold of persimmon (Diospyros kaki) caused by Penicillium crustosum. Res. Plant Dis. 9:217-220 (in Korean with English summary).

Kwon, J. H., and Park, C. S. 2003b. Sooty mold of persimmon (Diospyros kaki) caused by Cladosporium cladosporioides in Korea. Plant Pathol. J. 19:266-268.

Martínez-Calvo, J. M., Badenes, M. L., and Llácer, G. 2012. Descripción de nuevas variedades de caqui (Diospyros kaki Thunb.) del Banco de Germoplasma del IVIA. Monografías INIA. Serie Agrícola 28. Madrid, Spain. 73 pp (in Spanish).

Mendes, M. A. S., Silva, V. L., Dianese, J. C., Ferreira, M. A. S. V., Santos, C. E. N., Gomes Neto, E., Urben, A. F., and Castro, C. 1998. Fungos em Plantas no Brasil. Embrapa-SPI, Embrapa Cenargen, Brasília, Brasil. 555 pp (in Portuguese).

Nasu, H., Shintaro, F. and Yokoyama, T. 1985. Zygophiala jamaicensis Mason, a causal fungus of flyspeck of grape, Japanese persimmon, and apple. Ann. Phytopathol. Soc. Jpn. 51:536-545.

Ogawa, J. M., and English, H. 1991. Diseases of Temperate Zone Tree Fruit and Nut Crops. Pub. 3345, DANR, University of California, Oakland, CA, USA. $461 \mathrm{pp}$.

Palou, L., Montesinos-Herrero, C., Besada, C., and Taberner, V. 2013a. Postharvest fruit rot of persimmon (Diospyros kaki) in Spain caused by Lasiodiplodia theobromae and Neofusicoccum spp. J. Phytopathol. 161: 625-631.

Palou, L., Montesinos-Herrero, C., Guardado, A., Besada, C., and del Río M. A. 2009. Fungi associated with postharvest decay of persimmon in Spain. Acta Hortic. 833:275-280.

Palou, L., Montesinos-Herrero, C., Tarazona, I., and Taberner, V. 2013b. Postharvest anthracnose of persimmon fruit caused by Colletotrichum gloeosporioides first reported in Spain. Plant Dis. 97:691.

Palou, L., and Taberner, V. 2014. Etiología de las enfermedades de poscosecha del caqui (Diospyros kaki L. cv. Rojo Brillante) en España. Page 144 in: Actas XVII Congreso de la Sociedad Española de Fitopatología. Lleida, Catalonia, Spain (In Spanish).

Palou, L., Taberner, V., Guardado, A., and Montesinos-Herrero, C. 2012. First report of Alternaria alternata causing postharvest black spot of persimmon in Spain. Australas. Plant Dis. Notes 7:41-42.
Park, Y. S., Na, T. S., and Lee, L. M. 1997. Effects of $\mathrm{O}_{2}$ and $\mathrm{CO}_{2}$ treatments within polyethylene film bags on the fruit quality of non-astringent 'Fuyu' persimmon fruits during storage. J. Korean Soc. Hortic. Sci. 38:510-515.

Perez, A., Ben-Arie, R., Dinoor, A., Genizi, A., and Prusky, D. 1995. Prevention of black spot disease in persimmon fruit by gibberellic acid and iprodione treatments. Phytopathology 85:221-225.

Prusky, D., Ben-Arie, R., Guelfat-Reich, S. 1981a. Etiology and histology of Alternaria rot of persimmon fruits. Phytopathology 71:1124-1128.

Prusky, D., Eshel, D., Kobiler, I., Yakoby, N., Beno-Moualem, D., Ackerman, M., Zuthji, Y., and Ben-Arie, R. 2001. Postharvest chlorine treatments for the control of the persimmon black spot disease caused by Alternaria alternata. Postharvest Biol. Technol. 22:271-277.

Prusky, D., Fuchs, Y., and Zauberman, G. 1981b. A method for pre-harvest assessment of latent infections in fruits. Annu. Appl. Biol. 98:79-85.

Prusky, D., Kobiler, I., Akerman, M., and Miyara, I. 2006. Effect of acidic solutions and acidic prochloraz on the control of postharvest decay caused by Alternaria alternata in mango and persimmon fruit. Postharvest Biol. Technol. 42:134-141.

Prusky, D., Perez, Y., Zutkhi, Y., and Ben-Arie, R. 1997. Effect of modified atmosphere for control of black spot, caused by Alternaria alternata, on stored persimmon fruits. Phytopathology 87:203-208.

Raj, K., and Rana, B. S. 1987. Study of different packing materials on persimmon (Diospyros kaki L.) fruit rotting fungi. Progress. Hortic. 19:289-292.

Rheinländer, P. A., Sutherland, P. W., and Fullerton, R. A. 2013. Fruit infection and disease cycle of Botrytis cinerea causing cosmetic scarring in persimmon fruit (Diospyros kaki Linn.). Australas. Plant Pathol. 42:551-560.

Rotem, J., 1998. The Genus Alternaria. Biology, Epidemiology and Pathogenicity. 2nd ed. APS Press, St. Paul, Minnesota, USA. 326 pp.

Salvador, A., Arnal, L., Monterde, A., and Cuquerella, J. 2004a. Reduction of chilling-injury symptoms in persimmon cv. "Rojo Brillante" by 1-MCP. Postharvest Biol. Technol. 33:285-291.

Salvador, A., Cuquerella, J., Martinez-Jávega, J. M., Monterde, A., and Navarro, P. 2004b. 1-MCP preserves the firmness of stored persimmon 'Rojo Brillante'. J. Food Sci. 69:69-73.

Snowdon, A. L. 1990. A Color Atlas of Post-harvest Diseases and Disorders of Fruits and Vegetables, vol. 1, General Introduction and Fruits. CRC Press, Boca Raton, FL, USA. 302 pp.

Taguchi, Y., Watanabe, H., Akita, S., and Hyakumachi, M. 2001. Occurrence and control of ripe rot symptoms on persimmon fruit. Jpn. J. Phytopathol. 67:33-41.

Vicent, A., Mira, J. L., Taberner, V., and Palou, L. 2015. Enfermedades fúngicas de importancia en campo y almacén. Pages 241-275 in: El Cultivo del Caqui. M. L. Badenes, D. S. Intrigliolo, A. Salvador, and A. Vicent, eds. Generalitat Valenciana, Valéncia, Spain (In Spanish).

Weir, B. S., and Johnston, P. R. 2010. Characterisation and neotypification of Gloeosporium kaki Hori as Colletotrichum horii nom. nov. Mycotaxon 111 209-219.

White, T. J., Bruns, T., Lee, S., and Taylor, J. 1990. Amplification and direct sequencing of fungal ribosomal RNA genes for phylogenetics. Pages 315-322 in: PCR Protocols: A Guide to Methods and Applications. M. A. Innis, D. H. Gelfand, J. J. Sninsky, and T. J. White, eds. Academic Press Inc., San Diego, CA, USA.

Williamson, S. M., and Sutton, T. B. 2010. First report of anthracnose caused by Colletotrichum acutatum on persimmon fruit in the United States. Plant Dis. 94: 634

Xie, L., Zhang, J.Z., Lei, C. and Hyde, K.D. 2010. Biology of Colletotrichum horii, the causal agent of persimmon anthracnose. Mycology 1:242-253.

Yu, X., Qin, Z., Ai, C., Wang, H. and An, M. 2013. Isolation and identification of pathogen of 'Jirou' persimmon anthracnose disease from Yishui, Shandong, China. Acta Hort. 996:271-276.

Zhang, J, and Hu, D. 2004. Effects of environment factors on conidia germination, appressoria formation and pathogenicity of the persimmon anthracnose pathogen Colletotrichum gloeosporioides. Acta Phytopathol. Sin. 34:154-161 (in Chinese with English summary). 